\title{
BCL6 Gene Translocation
}

National Cancer Institute

\section{Source}

National Cancer Institute. BCL6 Gene Translocation. NCI Thesaurus. Code C134901.

A cytogenetic abnormality that refers to any translocation involving the BCL6 gene. 